UDC 519.876.2+612.018+612.015.1

H. CAO, ${ }^{1}$ W. ZHONG, ${ }^{1}$ W. WU, ${ }^{1}$ Q. TU, ${ }^{2}$ and X. TANG ${ }^{1}$

\title{
EFFECTS OF ATORVASTATIN ON E-SELECTIN AND MYELOPEROXIDASE EXPRESSIONS AFTER CEREBRAL ISCHEMIA-REPERFUSION INJURY IN RATS
}

\begin{abstract}
Received 28.10.2013
We examined expressions of E-selectin and myeloperoxidase (MPO) in cerebral tissues after cerebral ischemia-reperfusion (CIR) in rats and evaluated neuroprotective effects of atorvastatin under these conditions. Immunohistochemical methods were used to detect E-selectin and MPO expressioning tissue. Small numbers of E-selectin- and MPO-positive cells were observed in the sham group within 4 to $24 \mathrm{~h}$ time intervals. In the operation group, numerous positive cells were found in the cortex and hippocampus after CIR. E-selectin expression occurred at $4 \mathrm{~h}$, peaked at $12 \mathrm{~h}$, and returned to nearly normal levels at $24 \mathrm{~h}$. However, E-selectin expression in the intervention (CIR + atorvastatin) group was significantly lower than that in the operation group at each time $(P<0.05)$. Myeloperoxidase had nearly similar timing of changes in E-selectin expression, and MPO expressions at different time points in the intervention group were significantly lower than those in the operation group $(P<0.05)$. Therefore, expressions of E-selectin and MPO change dynamically after CIR. Atorvastatin, an agent having anti-inflammatory properties, demonstrates an obvious protective effect with respect to acute CIR-related damage.
\end{abstract}

KEYWORDS: cerebral ischemia-reperfusion (CIR), E-selectin, myeloperoxidase, atorvastatin, inflammation.

\section{INTRODUCTION}

Atorvastatin is a lipid-lowering drug used in therapy of cardio-cerebrovascular diseases where hyperlipidemia is a significant independent risk factor. The following questions seem to be logical: in addition to the lipidlowering effect in the above diseases, can atorvastatin also play a role in some other way, and can patients with normal blood lipid levels use statins?

Stroke is one of the three greatest threats to human health, with high morbidity, disability, and mortality. Cerebral ischemia-reperfusion is aggravated with inflammation, resulting in secondary injury to ischemic tissues $[1,2]$. There is a series of reactions developing after CIR, and inflammation is one of the main negative factors inducing secondary injury to ischemised tissues.

E-selectin plays an important role in the inflammatory cascade after CIR. This agent is an

\footnotetext{
${ }^{1}$ Department of Neurology, Second Xiangya Hospital of the Central South University, Changsha, China.

${ }^{2}$ Departments of Geriatrics, Third Xiangya Hospital of the Central South University, Changsha, China.

Correspondence should be addressed to X. Tang

(e-mail: txq6633@126.com).
}

inducible adhesion molecule that mediates adhesion between activated endothelial cells and neutrophils and is directly involved in aggregation and infiltration of inflammatory cells. Within the period following CIR injury, white blood cells travel through the blood vessel wall, interact with endothelial cells, and release a number of inflammatory factors. In brain ischemic tissues, the levels of mRNA of adhesion molecules are significantly increased, large amounts of adhesion molecules are synthesized, and the level of E-selectin correlates with the production of oxygen free radicals. Blocking of expression of E-selectin and suppression of adhesion processes and accumulation of neutrophils in the ischemic area can reduce death of neurons and limit the infarct volume. This may improve the prognosis in stroke patients. In models of cerebral ischemia, the survival rate of animals increased after anti-E-selectin antibody treatment. Myeloperoxidase, MPO, exists primarily in neutrophil azurophilic granules, and its activity is a reliable index accessing the infiltration of neutrophils in the tissues.

Statins function as both regulation and nonregulation agents with respect to lipids. In a number of studies, it was shown that statins can provide protection against renal, pulmonary, and heart 
ischemia-reperfusion injury [3-5]. However, there is no information about the effect of statins in the case of CIR injury. Our experiments were aimed at modeling of CIR, observation of the levels of expression of E-selectin and MPO, and investigation of the mechanism of possible anti-inflammatory actions of atorvastatin.

\section{METHODS}

Animal Groups. Sprague-Dawley rats were provided by the Laboratory animal center of the Xiangya Medical School of the Central South University (Changsha, China). A total of 96 rats weighing from 240 to $260 \mathrm{~g}$ were divided randomly into three groups, sham-operated, experimental (CIR), and intervention (CIR + atorvastatin) groups. In the latter group, each rat received daily $6.5 \mathrm{mg} / \mathrm{kg}$ atorvastatin one week before the operation; atorvastatin was dissolved in $0.9 \%$ normal saline (NS) and administered by gavage; other groups were given a gavage of NS of the same volume. Each group was further divided into subgroups surviving $4,8,12$, and $24 \mathrm{~h}$ after CIR.

Rat CIR Model. Focal CIR was modeled in rats according to the Longa suture method [6]. A siliconecoated nylon monofilament was inserted across bifurcation of the common carotid artery to the right internal carotid artery and then penetrated into the brain until a proximal occlusion of the right middle cerebral artery (MCA) was achieved. After 2 hours of occlusion, the filament was slowly withdrawn to allow the MCA blood supply to recover, and reperfusion was allowed to continue for 4, 8, 12 and $24 \mathrm{~h}$. Rats were anesthetized with isoflurane (4\% for surgical induction and $1.75 \%$ for a maintenance dose) for surgery. The body temperature was maintained at $37^{\circ} \mathrm{C}$. In the sham group, rats received only anesthesia and vascular separation.

Neurological Deficit Grading System. After revival of the rats from anesthesia, we observed neurological symptoms before selecting materials. Neurological deficit was estimated according to the Longa's Score in the following mode. Score 0 was given if the rat demonstrated no symptoms of neural damage; score 1 was given if the rat couldn't be fully extend the forelimbs; score 2 was given if the rat made circling movements to the opposite side; score 3 was given if the rat fell down to the opposite side, and score 4 was used if the rat couldn't walk spontaneously, with the loss of consciousness. Rats receiving scores 1 to 3 were selected as observational objectives.

Tissue and Slice Processing. Celiac anesthesia was achieved with $10 \%$ novochlorhydrate $(350 \mathrm{mg} / \mathrm{kg})$. After the perfusion procedure, the entire brain tissue was removed. We observed whether subarachnoid hemorrhage occurred at the skull base, and knocked out the ones that were bleeding. Then, the fixed brain tissue was sliced in continuous $4-\mu \mathrm{m}$ thick coronary sections sliced between the optic chiasm and leading edge of the pons, with conventional dehydration, hyalinization, wax soaking and embedding.

Triphenyl Tetrazolium Chloride (TTC) Staining. After anesthesia with $10 \%$ novochlorhydrate, brain tissue was removed from the skull and refrigerated at $-20^{\circ} \mathrm{C}$ for $30 \mathrm{~min}$. After that, five coronal slices were made with a $2 \mathrm{~mm}$ interval behind the frontal pole (at $1,3,5,7,9$, and $11 \mathrm{~mm}$ ) and incubated in darkness for 30 min with $2 \%$ TTC-PBS solution at a constant temperature $\left(37^{\circ} \mathrm{C}\right)$. Regions that were stained red were considered normal, while regions of cerebral infarction appeared white. After staining, sections were fixed for $24 \mathrm{~h}$ with $10 \%$ formaldehyde solution, and pictures were taken with a digital camera.

Immunohistochemical Staining. After dewaxation and hydration, brain tissue paraffin sections were washed with PBS buffer three times, each time for $5 \mathrm{~min}$. Then, each section was blocked with $50 \mu 1$ of a peroxidase-blocking solution (to block endogenous peroxidase activity) and incubated for $10 \mathrm{~min}$ at room temperature. Washed with PBS buffer three times, each section was incubated with $50 \mu$ of nonimmunologic animal serum for $10 \mathrm{~min}$ at room temperature prior to overnight incubation at $4{ }^{\circ} \mathrm{C}$ with $50 \mu \mathrm{l}$ monoclonal rabbit anti-mouse E-selectin antibody. Washed in PBS buffer ( 5 min, 3 times) each section was incubated with $50 \mu 1$ biotin-labeled sheep anti-rat IgG and $50 \mu 1$ Streptomyces-avidinperoxidase solution for $10 \mathrm{~min}$ at room temperature. Then each section was subjected to the action of 100 $\mu 1$ of freshly prepared AEC solution for $10 \mathrm{~min}$ and observed under a microscope. Brown-color cites were considered positive. Immunohistochemical results were processed by the MIAS medical image analysis system. Average grey values were selected to stand for the levels of expression of E-selectin and MPO. Polyclonal E-selectin antibodies $(1: 100)$ and polyclonal MPO antibodies (1:100) were purchased from Biosynthesis Biotechnology Co. (Beijing, China). Immunohistochemical staining protocols (SP method) and DAB coloration were used for 
amplification and visualization.

Statistical Analysis. Numerical results are expressed below as means \pm s.e.m. Differences between the groups were estimated by ANOVA or the LSD-test, and those with $P<0.05$ were considered to be statistically significant.

\section{RESULTS}

TTC Staining. Brain sections in the sham group were uniformly red (Fig. 1A). In the CIR group, blood supply to the lateral regions was significantly reduced, as was shown by the presence of infarcted white regions (shown in Fig. 1B with black arrow). The contralateral side remained red and, thus, well perfused. So, the CIR model was found to be successful.

E-Selectin Expression. Positive expression looked as was tan-yellow in the cell boundaries and cytoplasm. In the sham group, immunohistochemical staining showed that little E-selectin expression appeared within the cortical areas supplied by the middle cerebral artery $(4 \mathrm{~h}, 8.44 \pm 1.27 ; 8 \mathrm{~h}, 12.59 \pm 0.80$; $12 \mathrm{~h}, 13.89 \pm 1.29$, and $24 \mathrm{~h}, 9.85 \pm 1.05$; Figs. $2 \mathrm{~A}$; 4). In the operation (CIR) group, E-selectin expression peaked at $12 \mathrm{~h}$ after CIR. There was intense tan-yellow E-selectin-positive immune staining in the ischemized cerebral cortex $(4 \mathrm{~h}, 28.05 \pm 1.28 ; 8 \mathrm{~h}, 69.33 \pm 0.97$; $12 \mathrm{~h}, 84.19 \pm 1.06$, and $24 \mathrm{~h}, 60.43 \pm 1.33$; in all cases, $P<0.05$; Figs. 2B; 4). Expression of E-selectin in the intervention ( + atorvastatin) group peaked at $12 \mathrm{~h}$ after CIR. The level of expression in each time point in the intervention group was statistically lower than that in the operation group, but higher than that in the sham group $(4 \mathrm{~h}, 22.32 \pm 0.94 ; 8 \mathrm{~h}, 48.20 \pm 1.09 ; 12 \mathrm{~h}$, $62.93 \pm 0.94$, and $24 \mathrm{~h}, 41.47 \pm 1.18 ; P<0.05$ in all cases; Figs. 2C; 4).

MPO Expression. Positive cites were tan in their color. In the sham group, immunohistochemical staining showed that relatively low MPO expression appeared within the cortical areas supplied by the cerebral artery $(4 \mathrm{~h}, 7.98 \pm 1.05 ; 8 \mathrm{~h}, 7.79 \pm 1.26 ; 12 \mathrm{~h}$,
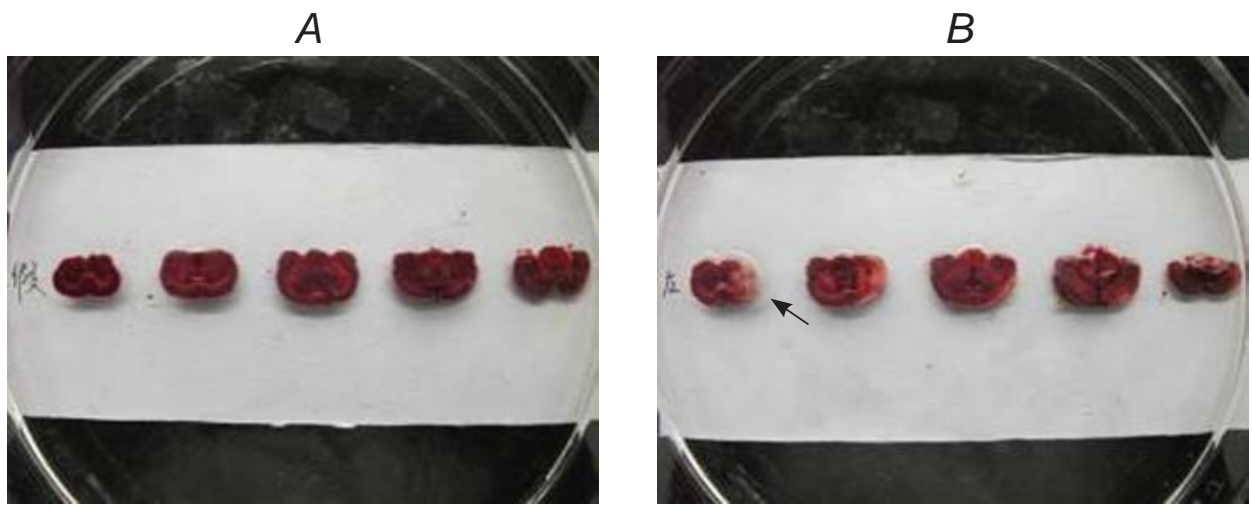

F i g. 1. Triphenyl tetrazolium chloride staining of brain sections in the sham (A) and operation (cerebral ischemia-reperfusion) group (B).

Р и с. 1. Забарвлення зрізів мозку тріфенілтетразолієм у групі контролю (А) та групі тварин після церебральної ішеміїреперфузії (B).

$A$



$B$

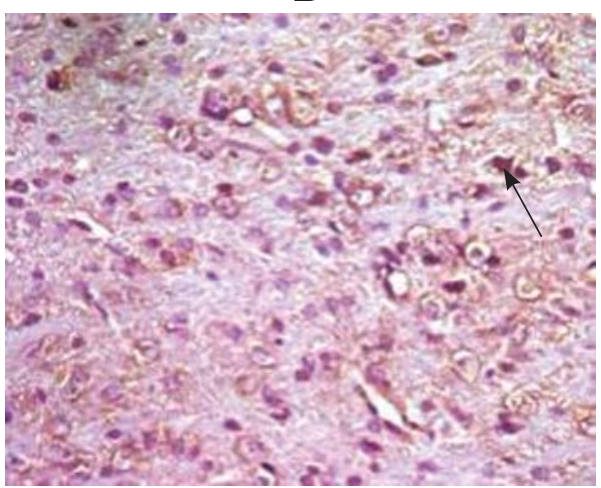

C

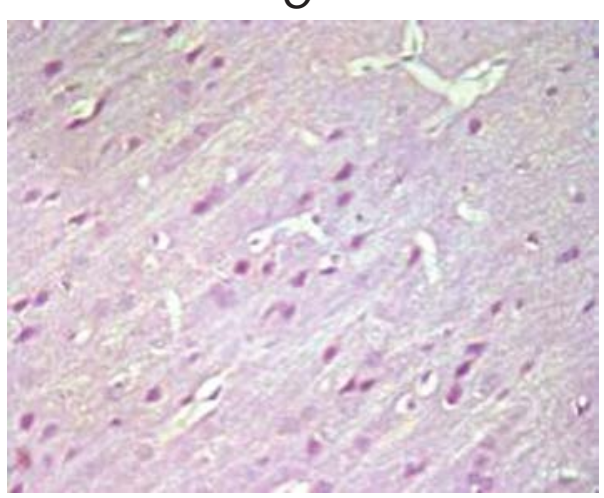

F i g. 2. Expression of E-selectin in the sham (A), operation (B), and intervention (C) groups; $12 \mathrm{~h}$ after sham operation (A) and cerebral ischemia-reperfusion $(\mathrm{B}$ and $\mathrm{C}) ; \times 400$.

Р и с. 2. Експресія Е-селектину в контрольних тварин $(A)$, щурів після церебральної ішемії-реперфузії - ЦІР (B) та щурів після ЦІР і введень аторвастатину $(C)$. 



F i g. 3. Expression of myeloperoxidase in the sham, operation, and intervention groups (A-C, respectively); $12 \mathrm{~h}$.

Р и с. 3. Експресія мієлопероксидази в трьох групах тварин ( $A-C$ відповідно).

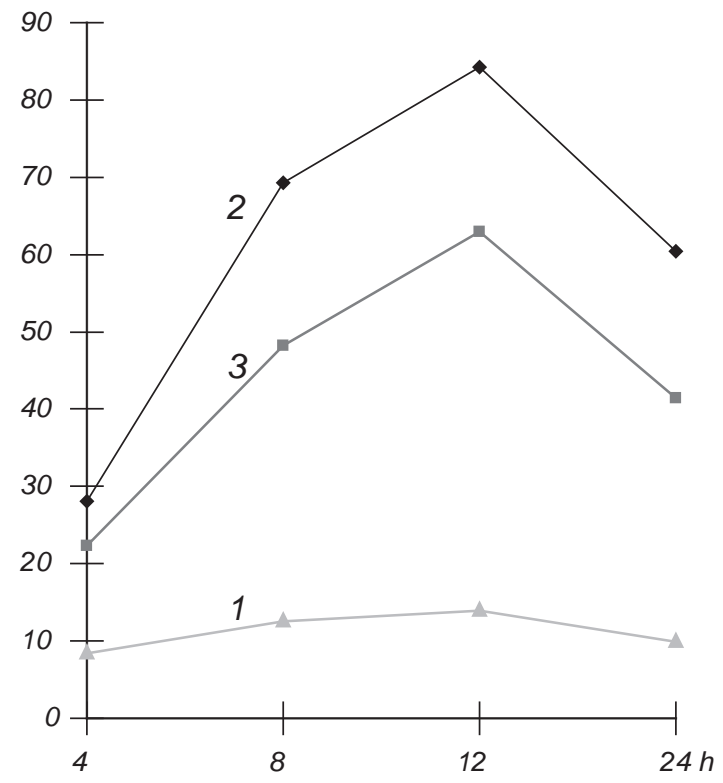

F i g. 4. Dynamics of E-selectin expression in the sham, operation, and intervention groups (1-3, respectively). Abscissa) Time, h; ordinate) optic density according to the grey scale.

Р и с. 4. Динаміка експресії Е-селектину в трьох групах тварин (1-3 відповідно).

$8.22 \pm 0.89$, and $24 \mathrm{~h}, 7.51 \pm 1.17$; Figs. 3A; 5). In the operation group, tan MPO immunostaining reached the maximum in the ischemic cerebral cortex 12 hours after CIR $(4 \mathrm{~h}, 15.95 \pm 2.00 ; 8 \mathrm{~h}, 20.45 \pm$ $\pm 1.97 ; 12 \mathrm{~h}, 21.75 \pm 2.61$, and $24 \mathrm{~h}, 18.10 \pm 0.49 ; P<$ $<0.05$ in comparisons with the respective sham values; Figs. 3B; 5). In the intervention group, MPO expression also peaked at $12 \mathrm{~h}$ after CIR. However, the levels of MPO staining at all time points were significantly lower than those in the operation group, but significantly

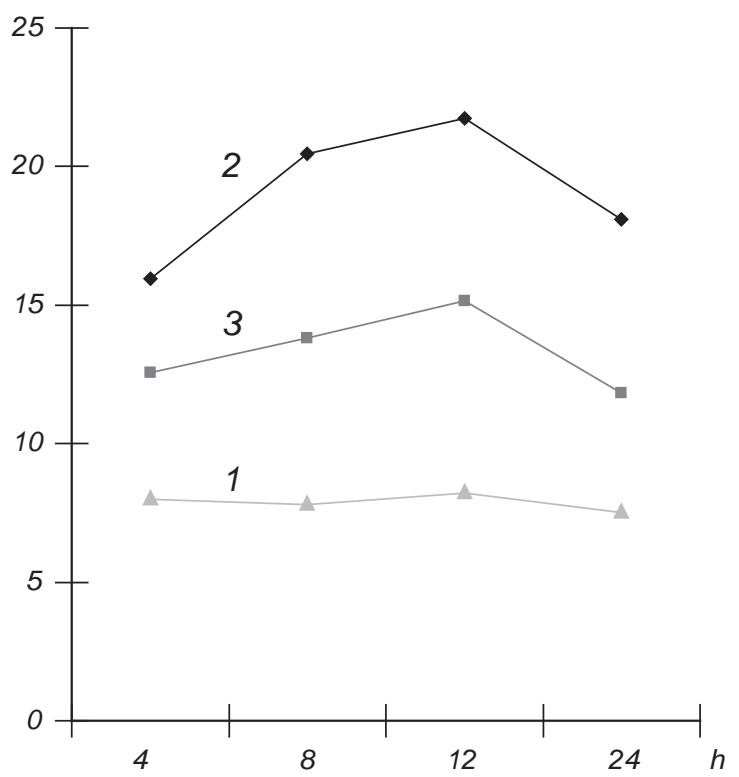

F i g. 5. Dynamics of myeloperoxidase expression in the sham, operation, and intervention groups (1-3, respectively). Designations are similar to those in Fig. 4.

P и с. 5. Динаміка експресії мієлопероксидази в трьох групах тварин (1-3 відповідно).

higher than those in the sham group $(4 \mathrm{~h}, 12.55 \pm$ $\pm 1.51 ; 8 \mathrm{~h}, 13.80 \pm 0.44 ; 12 \mathrm{~h}, 15.14 \pm 0.36$, and $24 \mathrm{~h}$, $11.84 \pm 0.33 ; P<0.05$ in all cases; Figs. $3 C ; 5)$.

\section{DISCUSSION}

Recent researches indicated that excessive inflammation in cerebral tissues after CIR is one of the main causes of the reperfusion injury [7]. Inflammation is 
characterized by infiltration by leukocytes, activation of vascular endothelial cells, and increase in the level of adhesion molecules on the surface of leukocytes, which led to obstruction of microvessels by rolling and adhering. This resulted in tissue damage because of crossing the endothelium tissue and releasing of such factors as reactive oxygen species, proteins, and lipids $[8,9]$. In some studies, it was demonstrated that clearing from peripheral leukocytes and/or inhibiting of the activity of leukocytes with certain drugs can protect cerebral tissues from negative consequences of ischemia-reperfusion $[10,11]$.

Selectin is one of the members of the adhesion molecule family, and it began to undergo intense research since it was cloned in 1989. The selectin family includes E-selectin, L-selectin, and P-selectin. E-selectin and L-selectin are, respectively, expressed in endothelial cells and white blood cells, while $\mathrm{P}$-selectin has been mainly found in platelets and endothelial cells. Normal platelets have no of small amounts of P-selectin on their surface. After CIR, $\mathrm{P}$-selectin can migrate to the surface of endothelial cells in a few minutes; it is involved in mediating initial adhesion of leukocytes and endothelial cells. Initial P-selectin-mediated adhesion is a short-lasting and reversible process; further interactions between white blood cells and endothelial cells are mediated by E-selectin. This selectin plays an important role in CIR-induced injury being involved in a late inflammatory response. E-selectin does not occur on the surface of endothelial cells and is not activated until endothelial cells are stimulated by inflammation. This is in accordance with our results that low levels of E-selectin expression were observed in the sham group, while such expression was dramatically higher in the operation group. In a primate stroke model, treatment with antibodies against adhesion molecular receptors reduced a "non-circulating flow" phenomenon. In the rat model with knockout of both $C D 18$ and $C D 26 E$ genes, adhesion of leukocytes was suppressed by $95 \%$. The effects with respect to E-selectin are specific and cannot be replaced by those with respect to any other adhesion molecule [12]. Glycogen with E-selectin antibody can crucially reduce adhesion and infiltration of leukocytes, leading to intensification of blood flow in the ischemized area and limitation of the cerebral infarction area [13]. Selectin is, at present, widely concerned as a new target for the drugs influencing adhesion of leukocytes during inflammation [14].

Immunohistochemistry showed that E-selectin is expressed in the ischemic lateral cortex, striatum, and hippocampus. Little expression was observed in the sham group, which confirmed what was found in previous studies [15]. After CIR, E-selectin expression demonstrated clear dynamics; it started at about $4 \mathrm{~h}$, peaked at $12 \mathrm{~h}$, and remained obvious at $24 \mathrm{~h}$ but with noticeable reduction. This timing of expression is close to that described in other reports $[16,17]$.

Myeloperoxidase is a peroxidase enzyme that in humans is encoded by the $M P O$ gene. This peroxidase is most abundantly expressed in neutrophil granulocytes (a subtype of white blood cells) and stored in azurophilic granules, which is the most reliable assessment biomarker of infiltration of neutrophils in the tissue. In our experiments, MPO was expressed in the ischemic lateral cortex, striatum, and hippocampus. There were few MPO-positive cells after CIR at each time point in the sham group, which agrees with previous reports. Compared with the above (sham) group, there were much more MPO positive cells in the cortex and hippocampus after CIR. Expression of MPO also changed dynamically (started at $4 \mathrm{~h}$, peaked at $12 \mathrm{~h}$, and remained at $24 \mathrm{~h}$ with significant reduction). Such timing of expression is similar to changes of E-selectin expression. The degrees of changes correlated with the degrees of neurological deficit. Thus, it can be speculated that changes in E-selctin expression are positively associated with the degree of inflammation.

Statins are defined as inhibitors of 3-hydroxy-3methylglutaryl-coenzyme A (HMG-CoA) reductase. These agents function better in reducing levels of low-density lipoproteins (LDLs) and other sorts of cholesterol-lowering drugs; meanwhile they increase the amount of high-density lipoproteins (HDLs). In addition, statins function "outside" of regulation of lipids, by improving the endothelial function, influencing the structure and stability of plaques, preventing thrombosis, and providing an antiinflammatory action. Mueck et al. [18, 19] found that fluvastatin can decrease the level of ICAM-1, VCAM-1, and E-selectin in a dose-dependent manner.

Our results showed that atorvastatin intervention statistically significantly decreases expression of E-selectin. The mechanism of cerebral protection by reducing E-selectin expression at present remains mostly unknown. However, according to some references, it is probably related to both lipid-lowering and non-lipid-lowering functions of atorvastatin.

Atorvastatin, when providing anti-inflammatory effects, lowers the levels of triglycerydes, cytokines (LDC-C and MCP-1) and increases the level of LDLs. 
There is evidence that HDLs can inhibit E-selectin expression. Increased E-selectin expression in the umbilical vein in humans and L1 overexpressing in pig aortic endothelial cells may be inhibited by HDLs [20]. Thus, it can be speculated that atorvastatin may raise the HDL amount to reduce E-selectin expression and, in such a way, contribute to cerebral protection.

$\mathrm{NF}-\kappa \mathrm{B}$ is a transcription factor widely expressed in eukaryotic cells, and it is proved to be activated under conditions of ischemic damage. Activated $\mathrm{NF}-\kappa \mathrm{B}$ regulates a series of gene expressions. Atorvastatin and calcium can inhibit expression of NF- $\kappa \mathrm{B}$ p $65 \mathrm{mRNA}$ and NF protein in cerebral tissues after ischemia-reperfusion, alleviating activation of NF- $\kappa \mathrm{B}$. The reduction of expression of proinflammatory molecules, in particular of adhesion ones, can lead to alleviation of the adhesion processes and congregation and infiltration of leukocytes in the ischemia areas, contributing to the reduction of CIR-related injury. Schneider et al. [6] utilized a gene knockout technology to conclude that, after $p 65$ knockout in Wistar rats, the infarct volume, water content in cerebral tissues, and neurological deficit were reduced more obviously than those in wild-type rats. Thus, it was concluded that activation of NF- $\mathrm{KB}$ can aggravate ischemic injury [6]. Similar experiments were conducted by Liu et al. [21]. Zhang et al. [22]

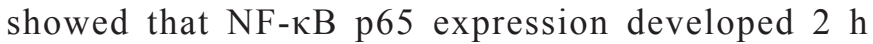
after cerebral ischemia, peaked at $12 \mathrm{~h}$, and attenuated gradually at $24 \mathrm{~h}$. The combination of TNF- $\beta$ and its receptors can activate $\mathrm{NF}-\kappa \mathrm{B}$ signal pathway, leading to integration of $\mathrm{NF}-\kappa \mathrm{B}$ in the core [23]. A general explanation is that activated $\mathrm{JNK} / \mathrm{p} 38$ kinase will phosphorylate c-JUN and bind promoters on the corresponding sites to regulate E-selectin expression.

It is probable that NF- $\kappa \mathrm{B}$ expression is the key upstream event resulting in intensification of the action of inflammatory factors and expression of adhesion molecules. According to our research, it is likely that atorvastatin impedes combination sites of E-selectin promoters in activated $\mathrm{NF}-\kappa \mathrm{B}$, inhibits $\mathrm{NF}-\kappa \mathrm{B}$ signals, and reduces activated E-selectin expression. Atorvastatin also inhibits the adhesion processes, limits infiltration of leukocytes and vessel endothelial cells, and in such a way contributes to cerebral protection by reducing pro-inflammatory damage after CIR. This statin is a promising neuroprotective agent in the cases of such injury. At the same time, the specific adjustment path is in this case not clear. We suspect that may be there is a relationship with $\mathrm{NF}-\kappa \mathrm{B}$; so, further studies of the atorvastatin influence on
$\mathrm{NF}-\kappa \mathrm{B}$ are expedient, to make clearer of how atorvastatin regulates inflammation to protect the brain tissue from ischemic-reperfusion injury.

So, administration of atorvastatin afforded noticeable protection to nerve tissues against the inflammation response and lipemic-oxidative injury under conditions of CIR. Atrovastatin improved lipid parameters and decreased the level of cerebral lipid peroxidation and inflammation. We conclude that atorvastatin is a prospective mean for treatment of ischemic cerebrovascular disease. Except lipidlowering effects, statins can bring the benefits for cerebrovascular disease patients with normal levels of blood lipids. At the same time, it should be recognized that only one dose was used in our experiments, and a dose-effect relationship should be examined in future, to make application of atorvastatin in clinics more well-based.

Acknowledgment. This work was supported by the Natural Science Foundation of Hunan Province, China (Grant No. 11JJ5081) and the Hunan Provincial Science and Technology Department, China (Grant No. 2012SK3226 and Grant No. 2011SK3236).

All experiments on animals were carried out in agreement with the international normative and approved by the Ethics Committee of the Central South University, Changsha, China.

The authors, H. Cao, W. Zhong, W. Wu, Q. Tu, and X. Tang, declare that they have no conflict of interest.

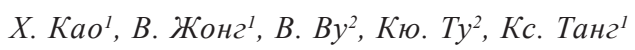

ВПЛИВ АТОРВАСТАТИНУ НА ЕКСПРЕСІЮ

Е-СЕЛЕКТИНУ ТА МІЄЛОПЕРОКСИДАЗИ ПІСЛЯ

УШКОДЖЕНЬ МОЗКУ ЩУРІВ, ПОВ' ЯЗАНИХ 3

ІШЕМІЕЮ-РЕПЕРФУЗІЕЮ

${ }^{1}$ Друга лікарня Ксіанг'я Центрального Південного

Університету, Чанша (Китай).

2 Третя лікарня Ксіанг'я Центрального Південного Університету, Чанша (Китай).

P е 3 ю м е

Ми досліджували експресію Е-селектину та мієлопероксидази (МПО) у тканинах мозку після церебральної ішеміїреперфузії (ЦІР) у щурів та оцінювали нейропротективний вплив аторвастатину в цих умовах. Для виявлення експресії Е-селектину та МПО були застосовані імуногістохімічні методики. У контрольній групі в проміжку 4-24 год спостерігалися невеликі кількості Е-селектин- та МПО-позитивних клітин. У групі, підданій ЦІР, у корі та гіпокампі відмічалася велика кількість позитивних клітин. Експресія Е-селектину 
проявлялася через 4 год, досягала максимуму через 12 год та поверталася до майже нормальних рівнів через 24 год. У той же час експресія Е-селектину в тварин, котрим уводили аторвастатин після ЦІР, у всіх часових проміжках була вірогідно нижчою, ніж у попередній групі $(P<0.05)$. Експресія МПО демонструвала часовий перебіг, приблизно подібний такому в експресії Е-селектину, і рівень експресії МПО в усіх часових інтервалах у групі, підданій дії аторвастатину, був істотно нижчим, ніж у групі без уведення цього агента $(P<0.05)$. Отже, експресія Е-селектину та МПО після ЦІР динамічно змінюється; аторвастатин - агент 3 антизапальною дією - продемонстрував очевидний протективний ефект щодо ушкоджень, індукованих гострою ЦІР.

\section{REFERENCES}

1. X. Ren, K. Akiyoshi, A. A. Vandenbark, et al., "Programmed death-1 pathway limits central nervous system inflammation and neurologic deficits in murine experimental stroke," Stroke, 42, No. 9, 2578-2583 (2011).

2. T. Miyazaki, Y. Kimura, H. Ohata, et al., "Distinct effects of tissue-type plasminogen activator and SMTP7 on cerebrovascular inflammation following thrombolytic reperfusion," Stroke, 42, No. 4, 1097-1104 (2011).

3. X. Wu, D. Lin, G. Li, and Z. Zuo, "Statin post-treatment provides protection against simulated ischemia in bovine pulmonary arterial endothelial cells," Eur. J. Pharmacol., 636, Nos. 1/3, 114-120 (2010).

4. J. L. Haylor, K. P. Harris, M. L. Nicholson, et al., "Atorvastatin improving renal ischemia reperfusion injury via direct inhibition of active caspase-3 in rats," Exp. Biol. Med., 236, No. 6, 755-766 (2011).

5. H. C. Xu, L. B. Qian, X. C. Ru, et al., "Electrophysiological effect of atorvastatin on isolated rat hearts injured by ischemia/ reperfusion," Zhejiang Da Xue Xue Bao Yi Xue Ban, 39, No. 6, 589-593 (2010).

6. A. Schneider, A. Martin-Villalba, F. Weih, et al., "NFkappaB is activated and promotes cell death in focal cerebral ischemia," Nat. Med., 5, No. 5, 554-559 (1999).

7. I. Ditnag, C. Iadecola, and M. Moskowitz, "Pathobiology of ischemic stroke: an integrated view," Trends Neurosci., 22, No. 9, 391-397 (1999).

8. B. A. Haines, S. L. Mehta, S. M. Pratt, et al., "Deletion of mitochondrial uncoupling protein-2 increases ischemic brain damage after transient focal ischemia by altering gene expression patterns and enhancing inflammatory cytokines," J. Cereb. Blood Flow Metab., 30, No. 11, 1825-1833 (2010).

9. A. Ottani, D. Giuliani, M. Galantucci, et al., "Melanocortins counteract inflammatory and apoptotic responses to prolonged myocardial ischemia/reperfusion through a vagus nervemediated mechanism," Eur. J. Pharmacol., 637, Nos. 1/3, 124130 (2010).

10. Y. Matsuo, H. Onodera, Y. Shiga, et al., "Correlation between myeloperoxidase-quantified neutrophil accumulation and ischemic brain injury in the rat. Effects of neutrophil depletion," Stroke, 25, No. 7, 1469-1475 (1994).

11. H. Chen, M. Chopp, and G. Bodzin, "Neutropenia reduces the volume of cerebral infarct after transient middle cerebral artery occlusion in the rat," Neurosci. Res. Commun., 93, No. 11, 9397 (2002).

12. M. Ali, A. E. Hicks, P. G. Hellewell, et al., "Polymers bearing sLex-mimetics are superior inhibitors of E-selectin-dependent leukocyte rolling in vivo," FASEB J., 18, No. 1, 152-154 (2004)

13. J. Huang, T. F. Choudhri, C. J. Winfree, et al., "Postischemic cerebrovascular E-selectin expression mediates tissue injury in murine stroke," Stroke, 31, No. 12, 3047-3053 (2000).

14. T. Zhou, J. L. Chen, W. Song, et al., "Effect of N-desulfated heparin on hepatic/renal ischemia reperfusion injury in rats," World J. Gastroenterol., 8, No. 5, 897-900 (2002).

15. H. Du, N. Liu, and Z. Wu, "Interleukin-10 inhibits of cerebral ischemia reperfusion E/ L-selectin expression," Chinese Med. J., 1, No. 89, 59-62 (2009).

16. J. Huang, T. F. Choudhri, C. J. Winfree, et al., "Postischemic cerebrovascular E-selectin expression mediates tissue injury in murine stroke," Stroke, 31, No. 12, 3047-3053 (2000).

17. C. J. Frijns and L. J. Kappelle, "Inflammatory cell adhesion molecules in ischemic cerebrovascular disease," Stroke, 33, No. 8, 2115-2122 (2002).

18. A. Mueck, H. Seeger, and D. Wallwiener, "Further evidence for direct vascular action of statin: effect on endothelial nitric oxide synthase adhesion molecules," Exp. Clin. Endocrinol. Diabets, 3, No. 1099, 181-183 (2001).

19. L. Wang, Y. Mei, and Z. Sun, "The changes of cerebral infarction patients' serum MCP-1 and the atorvastatin intervention role," Shanxi Med. Univ. Press, 4, No. 40, 344347 (2009).

20. G. W. Cockerill, T. Y. Huehns, A. Weerasinghe, et al., "Elevation of plasma high-density lipoprotein concentration reduces interleukin-1-induced expression of E-selectin in an in vivo model of acute inflammation," Circulation, 103, No. 1, 108-112 (2001).

21. R. Liu, L. Zhang, X. Lan, et al., "Protection by borneol on cortical neurons against oxygen-glucose deprivation/ reperfusion: involvement of anti-oxidation and antiinflammation through nuclear transcription factor kappaB signaling pathway," Neuroscience, 176, 408-419 (2011).

22. H. L. Zhang, M. Xu, C. Wei, et al., "Neuroprotective effects of pioglitazone in a rat model of permanent focal cerebral ischemia are associated with peroxisome proliferator-activated receptor gamma-mediated suppression of nuclear factorkappaB signaling pathway," Neuroscience, 176, 381-395 (2011).

23. M. A. Read, M. Z. Whitley, S. Gupta, et al., "Tumor necrosis factor alpha-induced E-selectin expression is activated by the nuclear factor-kappaB and c-JUN N-terminal kinase/p38 mitogen-activated protein kinase pathways," J. Biol. Chem., 272, No. 5, 2753-2761 (1997). 